\title{
PERIODONTAL DISEASE RELATED TO OXIDATIVE STRESS
}

Dirjanska Katerina ${ }^{1}$, Dejanova Beti², Petrovska Suncica ${ }^{2}$, Srejovic Ivan ${ }^{3}$, Selakovic Dragica ${ }^{3}$, Joksimovic Jovana ${ }^{3}$, Ivanovski Kiro ${ }^{1}$, Nakova Marija ${ }^{1}$, Dejanov Petar ${ }^{2}$

${ }^{1}$ Faculty of Dentistry, University of "Ss. Cirilius and Methodius" Skopje, Republic of Macedonia

${ }^{2}$ Faculty of Medicine, University of "Ss. Cirilius and Methodius" Skopje, Republic of Macedonia

${ }^{3}$ Department of Physiology, Faculty of Medical Sciences, University of Kragujevac, Republic of Serbia

\section{POVEZANOST PARODONTOPATIJE I OKSIDATIVNOG STRESA}

\author{
Dirjanska Katerina ${ }^{1}$, Dejanova Beti², Petrovska Sunčica ${ }^{2}$, Srejović Ivan ${ }^{3}$, Selaković Dragica ${ }^{3}$, Joksimović Jovana ${ }^{3}$, \\ Ivanovski Kiro ${ }^{1}$, Nakova Marija ${ }^{1}$ Dejanov Petar ${ }^{2}$ \\ 'Stomatološki fakultet, Univerzitet "Sveti Ćirilo i Metodije” Skoplje, Republika Makedonija \\ ${ }^{2}$ Medicinski fakultet, Univerzitet "Sveti Ćirilo i Metodije" Skoplje, Republika Makedonija \\ ${ }^{3}$ Katedra za fiziologiju, Fakultet medicinskih nauka, Univerzitet u Kragujevcu, Republika Srbija
}

Received / Primljen: 19.04.2013.

Accepted / Prihvaćen: 12.08.2013.

\section{ABSTRACT}

The study evaluates oxidative stress (OS) in patients with different stages of periodontal disease (PD) and the influence of their smoking habits on OS. PD is related to connective tissue inflammation, which leads to deterioration of the supporting structures of the tooth. OS is a condition characterised by overproduction of free radicals (FR), which may be involved in PD, causing periodontal tissue damage and other related diseases. Study patients' were grouped as I-non smokers ( $n=45)$ and II-smokers $(n=45)$; and consisted of patients with 3 PD stages: mild (1), moderate (2) and severe (3). As a control group, 30 healthy subjects (all non smokers) with no signs of PD were selected. FR levels were determined by the D-Roms test, total antioxidant capacity (AOC) was determined by the OXY-adsorbent test, (Diacron, Italy) and lipid peroxidation (LP) was determined by the fluorometric method with thiobarbituric acid and its end product, malonyldialdehyde (MDA). OS was found in the periodontal tissue and serum of PD patients, with the highest level of FR in the severe stage (3) in non smokers $(p<0.05)$ as well as smokers ( $p<0.01)$; AOC showed decreasing values from mild (1) to severe stage (3) of $P D$ for smokers $(p<0.05)$. LP in serum showed the highest level in severe stage (3) in both groups i.e., non smokers and smokers ( $p<0.05)$ compared to controls.

Based on the obtained results, we may conclude that PD is related to OS and may either be a cause or a trigger for more accelerated OS. Cigarette smoking increased FR production and is a serious factor exacerbating further tissue damage in PD. These findings may contribute to possible use of efficient antioxidant agents as a preventive measure for $P D$ and as a therapy for better disease outcome.

Key words: periodontal disease, oxidative stress, smoking.

\section{SAŽETAK}

Ova studija se bavi procenom oksidativnog stresa (OS) kod pacijenata sa razlicitim stadijumima oboljenja paradoncijuma - paradontopatija (PD), i uticaja pušačkih navika pacijenata. PD je povezana sa zapaljenjem vezivnih tkiva koje uzrokuje oštećenje tkivnog oslonca zuba. OS je stanje koje nastaje usled prevelike produkcije slobodnih radikala (SR) koji mogu biti uključeni u patogenezu PD, uzrokujući oštećenje paradontalnih tkiva $i$ drugih bliskih tkiva. Pacijenti su bili podeljeni u sledeće grupe: I - nepušači $(n=45)$, II - pušači $(n=45)$, koji su razvrstani na osnovu stadijuma PD na: blag (1), umeren (2), težak (3) i kontrolnu grupu (n=30). SR su određivani pomoću D-Roms testa, ukupni antioksidativni kapacitet (UAK) pomoću OXY-adsorbent testa (Diacron, Italija), a lipidna peroksidacija (LP) fluorometrijskom metodom pomoću tiobarbiturne kiseline $i$ njenog završnog metabolita, malonildialdehida (MDA). OS je detektovan u tkivu i serumu pacijenata sa PD: SR su pokazali najviši nivo kod pacijenata sa teškim stadijumom PD u grupi nepušača $(p<0.05)$ i pušača $(p<0.01)$; vrednosti UAK su se smanjivale od blagog (1) do teškog stadijuma (3) PD u grupi pušača (p<0.05). LP u serumu je imala najviši nivo u teškom stadijumu PD, i u grupi pušača $i$ u grupi nepušača $(p<0.05)$.

Na osnovu dobijenih rezultata možemo da zaključimo da je PD povezana sa OS, i može biti jedan od uzroka ili pokretačkih mehanizama za dinamičnije povećanje OS. Pušenje cigareta povećava nastajanje SR, i predstavlja značajan faktor daljeg oštećenja tkiva u PD. Ovi rezultati mogu da doprinesu mogućoj upotrebi antioksidativnih preparata u prevenciji PD, kao i terapiji, u cilju postizanja boljeg ishoda bolesti.

Ključne reči: paradontopatija, oksidativni stres, pušenje.

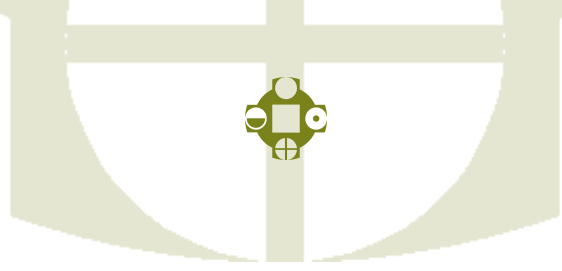




\section{INTRODUCTION}

The periodontal complex comprises alveolar bone, periodontal ligament, root cementum and the gingival tissue, all of which are crucial supporting structures of the tooth. Periodontal disease (PD) is characteriszed by chronic inflammation of the connective tissue leading to bone damage, which can be attributed to an impaired immune system. PD has also been linked to oral cancer, heart disease, stroke, osteoporosis, pre-term births, diabetes, and respiratory infections. Neutrophils that have been sequestered in the connective tissue and gingival sulcus attack bacteria and release enzymes that cause cell destruction, triggering oxidative stress (OS) by free radical (FR) production $(1,2)$. Internally generated FRs are from sources such as mitochondria, phagocytes, cytochrome P-450 reactions, peroxisomal fatty acid metabolism, xanthine oxidase and inflammation, where sources of externally generated FRs are cigarette smoking, air pollution, radiation, ultraviolet lights, chemicals, toxins, pathogenic microorganisms, etc. (3). Oxygen uptake in neutrophils is based on the flavoprotein cytochrome oxidase system, which increases NADPH production via hexose monophosphate shunt. Thus, it generates FRs such as superoxide anions, hydrogen peroxide, hydroxyl and hypochlorous acid. Due to unpaired electrons in the FR structure, they are highly reactive substances. Consequently, they are able to attack and damage cells by affecting lipids, proteins, carbohydrates and DNA molecules. They are capable of damaging either the cell membrane or certain bio-molecules, which leads to lipid peroxidation (LP), protein and DNA damage, enzyme oxidation and cytokine release (4). If the antioxidant capacity (AOC) is not sufficient to prevent and treat the cell impairment with the help of antioxidant enzymes, antioxidant molecules and some repair enzymes $(5,6)$, irreversible pathological processes may occur. This process may be accelerated by cigarette smoking, which has a likely role in periodontal disease progression. Severity of the disease may be proportional to the intensity of smoking (7). In addition to PD $(8,9,10)$, OS has been implicated in the pathogenesis of a number of diseases, such as diabetes mellitus, cardiovascular (11) and neurodegenerative diseases (12) and malignancies (13). The aim of this study was to evaluate OS in patients with different stages of PD and the influence of their smoking habits on OS.

\section{MATERIAL AND METHODS}

Ninety patients with PD aged $37 \pm 15$ years were divided into 2 groups: group I $(n=45)$ included patients who did not smoke cigarettes and group II $(\mathrm{n}=45)$ included patients who smoked cigarettes. As a control group, 30 healthy subjects (all non smokers) with no signs of PD were selected. Both patient groups were divided into 3 subgroups of 15 patients each, representing the 3 different disease stages, i.e., mild, moderate and severe PD, classified on the basis of anamnesis, clinical and roentgenographic examination. The clinical examination was performed using the dental plaque index based on the scale of Loe \& Silness, 1963 (14) to score the disease stage from 0 to 3 as follows: stage 0 - normal periodontal tissue, without plaque, which constituted the control group; stage 1 - mild inflammation with slight colour changes in periodontal tissue, slight edema and no bleeding on probing; stage 2 - moderate inflammation with redness, edema, glazing, bleeding on probing and presence of plaque in periodontal pocket, evident by visual examination; and stage 3 - severe inflammation with marked redness and edema, ulceration and tendency to spontaneous bleeding.

None of the patients had any detectable chronic disease, such as renal and liver failure or cardiovascular disease, or any other infection, neither were they given any medications. Roentgenographic examination confirmed the determined stage of PD and together with clinical examination and anamnesis contributed to the precise disease stage distinction. For laboratory testing, periodontal tissue and serum were used. The samples were taken during periodontal surgery in the course of normal treatment. After withdrawal, periodontal tissue was first measured, followed by addition of $1 \mathrm{ml}$ phosphate buffer and storage at a temperature of $-80^{\circ} \mathrm{C}$. The samples were homogenised for 5 minutes in Microson ultrasonic cell disruptor and centrifuged for 5 minutes at $5000 \mathrm{rpm}$. For serum, blood sample from cubital vein was centrifuged for 10 minutes at $3000 \mathrm{rpm}$ and stored at $-4^{\circ} \mathrm{C}$.

FRs were measured using the spectrophotometric method based ony the D-Roms test, AOC was measured using the OXY-adsorbent test (Diacron, Italy), and LP was determined by its end product malonyldialdehyde (MDA) using the modified fluorometric method with thiobarbituric acid (Ohkawa at al, 1978) (15). The degree of LP in serum and periodontal tissue was estimated by the modified fluorometric method, measuring thiobarbituric acid reactive substances (TBARS) using $1 \%$ TBA (Thiobarbituric acid) in $0.05 \mathrm{NaOH}$ incubated with serum and periodontal tissue at $100{ }^{\circ} \mathrm{C}$ for $15 \mathrm{~min}$ and read at $530 \mathrm{~nm}$. KrebsHenseleit solution was used as a blank probe.

For the statistical analysis, a Student t-test was used, and statistical significance was considered for $\mathrm{p}<0.05$.

\section{RESULTS}

In the control group, FRs showed higher values in serum $(293 \pm 68$ UCarr) than in periodontal tissue $(220 \pm 53$ UCarr) $(\mathrm{p}<0.05)$. However, no difference was found in AOC between periodontal tissue $(338 \pm 63 \mu \mathrm{molHCLO} / \mathrm{ml})$ and serum $(342 \pm 67 \mu \mathrm{molHCLO} / \mathrm{ml})$ in the control group. The level of LP in serum was $3.5 \pm 0.9 \mu \mathrm{mol} / \mathrm{l}$ in the control group. All obtained values in control group were considered as reference values (Table 1, 2, 3).

OS was found in both the periodontal tissue and the serum of PD patients. In the periodontal tissue, production 


\begin{tabular}{|c|c|c|c|c|}
\hline Subject groups & $\begin{array}{l}\text { Periodontal disease } \\
\text { Intensity }\end{array}$ & Number of cases & $\begin{array}{l}\text { Free radicals } \\
\text { UCarr }\end{array}$ & $\begin{array}{l}\text { Antioxidant capacity } \\
\mu \mathrm{mol} \mathrm{HCLO} / \mathrm{ml}\end{array}$ \\
\hline Healthy subjects (control group) & I & $\mathrm{n}=30$ & $220 \pm 53$ & $338 \pm 63$ \\
\hline \multirow{3}{*}{ PD patients (non smokers) } & Stage 1 & $\mathrm{n}=15$ & $323 \pm 75$ & $329 \pm 77$ \\
\hline & Stage 2 & $\mathrm{n}=15$ & $400 \pm 71^{*}$ & $298 \pm 69$ \\
\hline & Stage 3 & $\mathrm{n}=15$ & $440 \pm 88^{*}$ & $290 \pm 85$ \\
\hline \multirow{3}{*}{ PD patients (smokers) } & Stage 1 & $\mathrm{n}=15$ & $396 \pm 67 *$ & $297 \pm 79$ \\
\hline & Stage 2 & $\mathrm{n}=15$ & $439 \pm 72^{* * *}$ & $288 \pm 53^{*}$ \\
\hline & Stage 3 & $\mathrm{n}=15$ & $528 \pm 90 \% *$ & $267 \pm 55^{*}$ \\
\hline
\end{tabular}

Table 1: OS markers in periodontal tissue in non smokers and smokers with different PD stages

*, $\mathrm{p}<0.05 ; * \%, \mathrm{p}<0.01$

of FR progressively increased from mild, i.e., stage 1, to severe, i.e., stage 3 of PD. It showed the highest level in stage

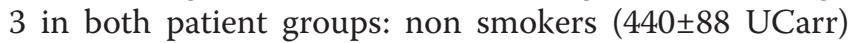
$(\mathrm{p}<0.05)$ and smokers $(528 \pm 90$ UCarr $)(\mathrm{p}<0.01)$. The AOC of periodontal tissue progressively decreased from stage 1 to stage 3 of PD with statistical significance in smokers $(267 \pm 55 \mu \mathrm{molHCLO} / \mathrm{ml})(\mathrm{p}<0.05)$ (Table 1$)$.
In serum, FR production was progressively increased from stage 1 to stage 3 of PD. It showed the highest level in stage 3 in both groups, non smokers (371 \pm 75 UCarr) $(\mathrm{p}<0.05)$ and smokers $(410 \pm 79$ UCarr $)(\mathrm{p}<0.01)$. In serum, AOC showed decreasing values from stage 1 to stage 3 of PD, with statistical significance in smokers $(292 \pm 61$ $\mu \mathrm{molHCLO} / \mathrm{ml})(\mathrm{p}<0.05)$ (Table 2).

\begin{tabular}{|l|l|l|l|l|}
\hline Subject groups & $\begin{array}{l}\text { Periodontal } \\
\text { inflammation Intensity }\end{array}$ & Number of cases & $\begin{array}{l}\text { Free radicals } \\
\text { UCarr }\end{array}$ & $\begin{array}{l}\text { Antioxidant capacity } \\
\mu \text { mol HCLO/ml }\end{array}$ \\
\hline Healthy subjects (control group) & \multicolumn{1}{|c|}{$/$} & $\mathrm{n}=30$ & $293 \pm 68$ & $342 \pm 67$ \\
\hline \multirow{4}{*}{ PD patients (non smokers) } & Stage 1 & $\mathrm{n}=15$ & $295 \pm 50$ & $337 \pm 73$ \\
\cline { 2 - 5 } & Stage 2 & $\mathrm{n}=15$ & $332 \pm 63$ & $340 \pm 79$ \\
\cline { 2 - 5 } & Stage 3 & $\mathrm{n}=15$ & $371 \pm 75^{*}$ & $327 \pm 64$ \\
\hline \multirow{3}{*}{ PD patients (smokers) } & Stage 1 & $\mathrm{n}=15$ & $334 \pm 61$ & $330 \pm 77$ \\
\cline { 2 - 5 } & Stage 2 & $\mathrm{n}=15$ & $385 \pm 65^{*}$ & $300 \pm 63$ \\
\cline { 2 - 5 } & Stage 3 & $\mathrm{n}=15$ & $410 \pm 79^{* *}$ & $292 \pm 61^{*}$ \\
\hline
\end{tabular}

Table 2: OS markers in serum of non smokers and smokers with different PD stages

FRs from periodontal tissue in stage 3 of $\mathrm{PD}$ were

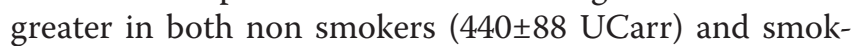
ers (528 \pm 90 UCarr) compared with reference values of the control group (220 \pm 53 UCarr). FRs showed similar trends, albeit of a lesser magnitude, when serum samples of stage 3 PD in both non smokers ( $371 \pm 75$ UCarr) as well as smokers (410 \pm 79 UCarr) were compared with controls $(293 \pm 68$ UCarr) (Figure 1).

UCarr

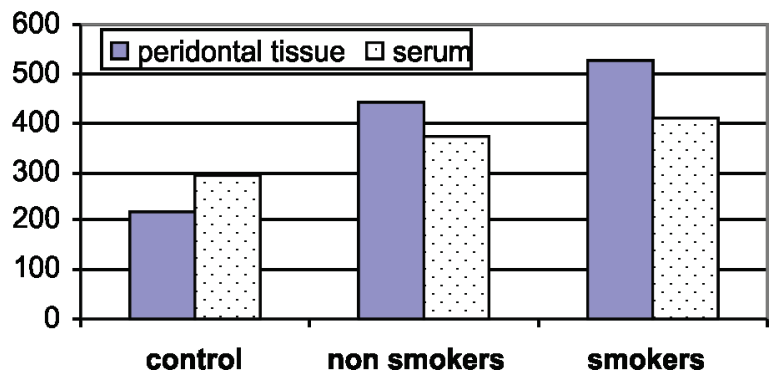

Figure 1: Free radicals in stage 3 of non smokers and smokers with PD
Compared with the reference values from the control group $(338 \pm 63 \mu \mathrm{molHCLO} / \mathrm{ml})$, AOC of periodontal tissue showed greater reduction in values in stage 3 of PD in both non smokers $(290 \pm 85 \mu \mathrm{molHCLO} / \mathrm{ml})$ and smokers $(267 \pm 55 \mu \mathrm{molHCLO} / \mathrm{ml})$. Compared to controls $(342 \pm 67$ $\mu \mathrm{molHCLO} / \mathrm{ml})$, though AOC showed similar decrements in serum from stage $3 \mathrm{PD}$ in both non smokers $(327 \pm 64$ $\mu \mathrm{molHCLO} / \mathrm{ml})$ and smokers $(292 \pm 61 \mu \mathrm{molHCLO} / \mathrm{ml})$, the magnitude of change was lesser than that in periodontal tissue (Figure 2).

\section{$\mu \mathrm{molHCLO} / \mathrm{ml}$}

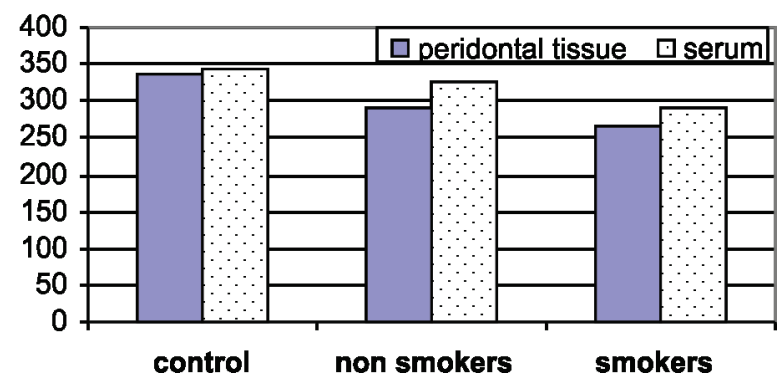

Figure 2: Antioxidant capacity in stage 3 of non smokers and smokers with PD 


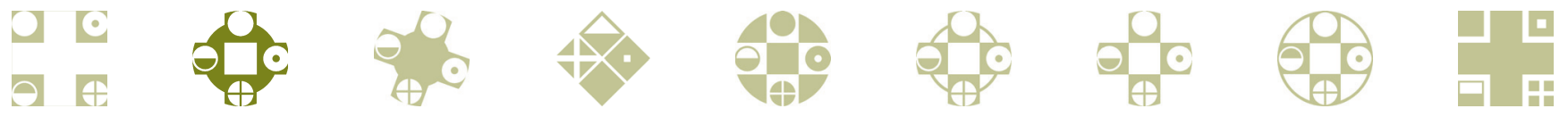

\begin{tabular}{|l|l|l|l|}
\hline \multirow{2}{*}{ Subject groups } & $\begin{array}{l}\text { Periodontal } \\
\text { inflammation intensity }\end{array}$ & Number of cases & $\begin{array}{l}\text { Lipid peroxidation (MDA) } \\
\mu \text { mol/1 }\end{array}$ \\
\hline Healthy subjects (control group) & \multicolumn{1}{|c|}{$/$} & $\mathrm{n}=30$ & $3.5 \pm 0.9$ \\
\hline \multirow{4}{*}{ PD patients (non smokers) } & Stage 1 & $\mathrm{n}=15$ & $3.4 \pm 1.0$ \\
\cline { 2 - 4 } & Stage 2 & $\mathrm{n}=15$ & $3.5 \pm 1.2$ \\
\cline { 2 - 4 } & Stage 3 & $\mathrm{n}=15$ & $3.9 \pm 0.9^{*}$ \\
\hline \multirow{3}{*}{ PD patients (smokers) } & Stage 1 & $\mathrm{n}=15$ & $4.0 \pm 1.3^{*}$ \\
\cline { 2 - 4 } & Stage 2 & $\mathrm{n}=15$ & $4.2 \pm 1.2^{*}$ \\
\cline { 2 - 4 } & Stage 3 & $\mathrm{n}=15$ & $4.1 \pm 1.1^{*}$ \\
\hline
\end{tabular}

Table 3: OS markers in serum of non smokers and smokers with different PD stages

LP in serum of PD patients demonstrated progressively increasing values from stage 1 to stage 3 of PD. The highest level of LP observed in stage 3 was significantly greater than controls in both non smokers $(3.9 \pm 0.9 \mu \mathrm{mol} / \mathrm{l})(\mathrm{p}<0.05)$ and smokers $(4.1 \pm 1.1 \mu \mathrm{mol} / \mathrm{l})(\mathrm{p}<0.05)$ (Table 3$)$.

\section{DISCUSSION}

Although FR showed higher values in serum than in periodontal tissue in healthy subjects, increasing FR production towards the severe stage of PD was much more evident in periodontal tissue in both non smokers and smokers. This is most likely because intravascular fluid is more frequently replenished with antioxidant agents such as albumin, bilirubin, uric acid, glutathione, ascorbic acid, and ubiquinol, which do not allow rapid FR increase in serum compared to periodontal tissue.

Concerning disease severity, higher the stage of $\mathrm{PD}$, the more severe OS observed. This relationship was even more evident in the group of smokers suffering from PD. Thus, OS was demonstrated by increased FR and decreased AOC in periodontal tissue and serum of the patient groups, and also by increased serum LP process. The imbalance between the antioxidant defence and repair system and pro-oxidant mechanism of cell damage leads to tissue destruction either by increased free radical production or by a lowered AOC defence (16).

FRs such as superoxide anion, hydrogen peroxide and hydroxyl radicals, produced by neutrophils, can attack biological molecules. As an initial product, superoxide anion, generated by the molecular oxygen reduction under NADPH oxidase increases cell oxygen consumption, activates several cell surface $G$ proteins and provokes a cascade of events, resulting in cell damage (17). Hydroxyl radicals damage important molecules, such as DNA, proteins and lipids; hydrogen peroxide is known to cross nuclear membrane and damages DNA; and superoxide anion is involved in bone reabsorption. Moreover, hydrogen peroxide stimulates phosphorylation of nuclear factor kappa $\beta(\mathrm{NFk} \beta)$ complex and facilitates nuclear translocation and causes production of proinflammatory cytokines including interleukin-2 (Il-2), interleukin-6 (Il-6), interleukin-8 (Il-8), $\beta$-interferon and tumour necrosis factor- $\alpha$
$(\mathrm{TNF}-\alpha)$. All of these agents are well known as very important factors in the PD pathogenesis (18). Cigarette smoking boosts FR production in patients with $\mathrm{PD}$, which is most evident in the severe stage of disease. This might be due to increased antioxidant consumption in smokers which impairs antioxidant body defence and causes OS progression. Systemic and local MDA as an end product of LP is increased by smoking and has a strong relation with the inflammation of periodontal tissue. Concerning low AOC, decreased activity of antioxidant enzymes such as superoxide dismutase, glutathione peroxidase and catalase might be caused by smoking. Inflammation is greater in periodontal tissue of smokers, which can be a cause of increased metallothionein as a free radical scavenger (19, 20). In the study of Garg N. et al, 2006, in smokers, the analysed parameters such as LP, superoxide dismutase, catalase, glutathione and total thiol showed increased OS proportionally related to the number of cigarettes smoked per day (21). Nicotine affects gingival blood flow, cytokine production, neutrophil and other immune cell function, as well as connective tissue turnover, all of which can be responsible for overall effects on periodontal tissues (22, 23). Furthermore, involvement of salivary differed histamine and increased salivary calcium in smokers exacerbates PD $(24,25)$. Antioxidant agents may overcome this impairment and may attenuate disease progression by down regulating glutathione detoxification / redox buffering system and by inhibiting key transcription factors, which lead to bone reabsorption. The factors such as forkhead box (FoxOs) family members induce the expression of genes controlling defence against OS and promote cell survival by inhibiting cyclin in cell cycle. The stage of PD, linked to smoking, may be a critical marker of a susceptible immune system, also initiating cancer risk by a prooxidant inflammatory profile $(26,27,28)$.

\section{CONCLUSION}

Based on our results, we may conclude that OS has a great influence on PD pathogenesis, which may also be a trigger mechanism leading to a further periodontal damage. This process may be further accelerated by cigarette smoking, thus revealing the link between nicotine presence 
and increased FR production. More studies are required to clarify the therapeutic effects of efficient antioxidant agents for PD to arrest further periodontal tissue damage and contribute to better disease outcome.

\section{REFERENCES}

1. Grant M, Brock G, Matthews J, Chapple I. Crevicular fluid glutathione levels in periodontitis and the effect on non surgical therapy. J Clin Perio 2010; 37: 17-23.

2. Takane M, Sugano N, Ezawa T, Uchiyama T, Ito K. A marker of oxidative stress in saliva: association with periodontally-involved teeth of a hopeless prognosis. J Oral Sci 2005; 47 (1): 53-7.

3. Kumar S. Free radicals and antioxidants. Adv Appl Sci Res 2011; 2(1): 129-35.

4. Battino M, Bullon P, Wilson M, Newman H. Oxidative injury and inflamatory periodontal diseases: the challenge of anti-oxidants to free radicals and reactive oxygen species. Crit Rev Oral Biol Med 1999; 10 (4): 458-76.

5. Benzie IF. Evolution of antioxidant defence mechanisms. Eur J Nutr 2000; 39(2): 53-61.

6. Blokhina O, Virolainen E, Faqerstedt KV. Antioxidants, oxidative damage and oxygen deprivation stress: a review. Ann Bot 2003; 91: 179-94.

7. Pejcic A, Obradovic R, Kesic L, Kojovic D. Smoking and periodontal disease. A review. Medicine and Biology 2007; 14 (2): 53-9.

8. Soory M. Oxidative stress induced mechanisms in the progression of periodontal diseases and cancer: a common approach to redox homeostasis? Cancer 2010; 2: 670-92.

9. Aiuto FD, Nibali L, Parkar M, Patel K, Suvan J, Donos N. Oxidative stress, systemic inflamation and severe periodontitis. J Dent Res 2010; 11: 1241-1246.

10. Pendyala G, Thomas B, Kumari S. The challenge of antioxidants to free radicals in periodontitis. J Indian Soc Periodontol 2008; 12(3):79-83.

11. Maritim AC, Sanders RA, Watkins JB. Diabetes, oxidative stress, and antioxidants: a review. J Biochem Mol Toxicol 2003; 17(1):24-38.

12. Uttara B, Singh AV, Zamboni P, Mahajan RT. Oxidative stress and neurodegenerative disease: a review of upstream and downstream antioxidant therapeutic options. Curr Neuropharmacol 2009; 7(1): 65-74.

13. Benz CC, Yau C. Ageing, oxidative stress and cancer: paradigms in parallax. Nat Rev Cancer 2008; 8(11): 875-9.
14. Loe H, Silness J. Periodontal disease in pregnancy. I. Prevalence and severity. Acta Odontol Scand 1963; 21:533-51.

15. Hiroshi O. Ohishi N, Yagi K. Assay for lipid peroxidation in animal tissues by thiobarbituric reaction. Analytical Biochem 1979; 95 (2): 351-8.

16. Chapple ILC. Role of free radicals and antioxidants in the pathogenesis of the inflammatory periodontal diseases. J Clin Pathol: Mol Pathol 1996; 49: M247-M255.

17. Van Dyke TE, Serhan CN. Resolution of inflammation: a new paradigm for the pathogenesis of periodontal diseases. J Dent Res 2003; 82(2):82-90.

18. Borges I, Addison Machado Moreira E, Filho DW, Bittencourt de OliveiraT, Spirelle da Silva MB, Silvia Frode T. Proinflammatory and oxidative stress markers in patients with periodontal disease. Mediators Inflamm 2007;1-5.

19. Tonguc MO, Ozturk O, Sutcu R, at al. J Periodont 2011; 82(9): 1320-8.

20. Katsuragi H, Hasegawa A, Saito K. Distribution of metallothionen in cigarette smokers and non-smokers in advanced periodontitis patients. J Periodont 1997; 68(10):1005-9.

21. Garg N, Singh R, Dixit J, Jain A, Tewari V. Levels of lipid peroxides and antioxidants in smokers and nonsmokers. J Periodontal Res 2006; 41(5): 405-10.

22. Malhotra R. Nicotine and periodontal tissues. J Indian Soc Periodont 2010; 14: 72-9.

23. Luthra K, Grover HS, Aggarwal N, Luthra S. Smoking swings of gingival crevicular fluid secretion. J Indian Soc Periodontol 2012; 16(1): 101-3.

24. Berti K, Haririan H, Laky M, Matejka M, Andrukhov O, Rauusch-Fan X. Smoking influences salivary histamine levels in periodontal disease. Oral Diseases 2012; 18: 410-16.

25. Sutej I, Peros K, Benutic A, Capak K, Basic K, RosinGrget K. Salivary calcium concentration and periodontal health of young adults in relation to tobacco smoking. Oral Health Prev Dent 2012; 10(4): 397-403.

26. Galli C, Passeri G, Macaluso GM. FoxOs, Wnts and oxidative stress-induced bone loss: new players in the periodontitris arena? J Periodont Res 2011; 46: 397-406.

27. Soory M. Oxidative stress induced mechanisms in the progression of periodontal diseases and cancer: a common approach to redox homeostasis? Cancers 2010;2(2): 670-92.

28. Genco RJ, Borqnakke WS. Risk factors for periodontal disease. Periodontol 2000 2013; 62(1): 59-94. 